Article

\title{
An Analysis of Professional Perceptions of Criteria Contributing to Sustainable Housing Affordability
}

\section{Emma Mulliner ${ }^{1}$ and Vida Maliene ${ }^{1,2, *}$}

1 School of the Built Environment, Liverpool John Moores University, Cherie Booth, Byrom Street, Liverpool L3 3AF, UK; E-Mail: E.K.Mulliner@ljmu.ac.uk

2 Institute of Land Management and Geomatics, Faculty of Water and Land Management, Aleksandras Stulginskis University, Universiteto 10, Akademija, Kaunas 53361, Lithuania

* Author to whom correspondence should be addressed; E-Mail: v.maliene@ljmu.ac.uk; Tel.: +44-151-231-2121.

Academic Editor: Tan Yigitcanlar

Received: 13 October 2014 / Accepted: 17 December 2014 / Published: 29 December 2014

\begin{abstract}
Housing affordability is a multi-dimensional issue, yet it is typically defined and assessed quite narrowly in terms of financial criteria. The housing affordability problem encompasses more than financial costs of housing and extends to larger issues of social wellbeing and sustainability. Accordingly, a broader range of factors ought to be considered when defining and assessing affordability, particularly if more sustainable outcomes are desired from housing. A comprehensive system of criteria representing sustainable housing affordability, developed by the authors, is validated and analysed in this paper. The quantitative data analysis of surveys conducted with housing and planning professionals across the UK is used to determine stakeholder's perceptions on the criteria contributing to sustainable housing affordability and to rank these criteria according to their importance. The paper establishes that professional opinions on this issue differ insignificantly across different regions of the UK, while it varies to some extent depending on the sector of housing industry.
\end{abstract}

Keywords: housing affordability; sustainability; professional opinion; criteria; quantitative analysis 


\section{Introduction}

The concept of housing affordability is by no means a new one. By 1990, "affordability" had become a common term in UK housing policy [1] and it has continued to be an increasingly important policy issue across the globe [2-10]. Nevertheless, although there is abundant discussion about housing affordability [11-13], a specific definition of the concept remains unclear and challenging in both academic and policy environments which means it is difficult to build consensus on the meaning. Gabriel et al. [14] point out that different interest groups struggle to impose their own definition of the problem and solutions to address it.

Comparing the relationship between housing expenditure (rent or mortgage) and household income is certainly the most common way to define and express housing affordability internationally [1,15-17]. However, the concept is multi-dimensional and goes much wider than this traditional notion. Conceptualising and measuring affordability in this manner focuses only on financial attributes and fails to deal with wider social and environmental issues such as housing quality, location and access to services and facilities. OECD countries are increasingly recognising the need for a broader and more encompassing understanding of housing affordability along these lines [14,18]. The paper frames the housing affordability problem as encompassing more than financial costs of housing and extends to larger issues of social wellbeing and community sustainability. The principal objective of this paper is to establish, validate and analyse a comprehensive set of criteria by which housing affordability can be assessed in a holistic and sustainable manner and to validate and determine the significance of the criteria using professional opinion. While it is clear from the literature in Section 2 that academic environments are beginning to have wider consideration for the factors that influence housing affordability, it is not clear whether industry professionals' views are in line with this. Accordingly, the criteria are validated using a questionnaire undertaken with professional respondents. The questionnaire sought to determine how important, if at all, each criterion is perceived to be. Furthermore, it has been stressed that the literature often neglects the role played by professional interest groups and lobbyists in defining problems such as affordability, with different interest groups struggling to impose their own definition of the problem [14]. In light of this view, along with other researchers highlighting the lack of consensus on the meaning of affordability [19,20], the quantitative analysis presented sought to determine if different groups of professional respondents had differing opinions on criteria importance. Specifically, the analysis examines whether professional opinion varies depending on the UK region that the professional is located, and sector of the housing industry that they are employed in.

\section{Defining and Conceptualising Housing Affordability}

The ambiguity surrounding the concept of affordability was initially raised as a concern by researchers in the 1990s, both in the UK and the US, who suggested that the meaning of the term needed to be clarified or its use should be discontinued [21,22]. Bramley [19] (p. 10) indicates that "the lack of official clarity on definitions reflects inherent ambiguities to the housing affordability concept as well as political caution or expediency". Over a decade after such concerns were brought to the fore, Stone [20] posed concerns that both academic and policy environments are inconsistent with the notion of affordability. Internationally, a number of other authors have also stressed that the notion is still unclear 
and lacks concise definition [11,23-25]. Nonetheless, the term is still continually used internationally, often without much consideration for its meaning.

Why is the concept so difficult to grapple with? In part this is due to the multi-dimensionality of the issue. Quigley and Raphael [26] advocate that the difficulty in defining affordability arises because:

Affordability...jumbles together in a single term a number of disparate issues: the distribution of housing prices, the distribution of housing quality, the distribution of income, the ability of households to borrow, public policies affecting housing markets, conditions affecting the supply of new refurbished housing, and the choices that people make about how much housing to consume relative to other goods. This mixture of issues raises difficulties in interpreting even basic facts about housing affordability (pp. 191-192).

Despite the recognition of such issues surrounding the concept, a plethora of definitions have been provided. One of the most widely quoted definitions of affordability comes from MacLennan and Williams [22]:

Affordability is concerned with securing some given standard of housing (or different standard) at a price or a rent which does not impose, in the eye of some third party (usually the government) an unreasonable burden on household incomes. A number of judgments and assumptions are made in putting the concept into practice, and, in broad terms, affordability is assessed by the ratio of a chosen definition of housing costs to a selected measure of household income in some given period (p. 9).

However, the "given standard" and "unreasonable burden on household incomes" are not specified. Bramley [27] (p. 16) advises more specifically that "households should be able to occupy housing that meets well established (social housing) norms of adequacy (given household type and size) at a net rent which leaves them enough income to live on without falling below some poverty standard". Note that both definitions define affordability as the relationship between housing costs and income but are also concerned with standards of housing consumption. In other words, affordability implies the ability of households to pay the costs of housing without imposing constraints on living costs [28]. Hancock [29] (p. 144) similarly proposes that "any rent will be affordable, which leaves the consumer with socially-acceptable standard of both housing and non-housing consumption after rent is paid". Chaplin et al. [30] (p. 6) affirm that "definitions of affordability must clearly take account not only of the cost of housing, but of housing standards and the price of other necessities of life". Freeman et al. [31] (p. 2) provide a simpler definition which does not focus on standards but asserts that "Definitions of affordability concentrate on the relationship between housing expenditure and household income and define a standard in terms of that income above which housing is regarded as unaffordable". In a similar manner Field [32] quite simply explains that affordability involves making normative judgments about the proportion of income a household should pay for housing (rent or monthly ownership) costs. The literature generally suggests that affordability basically relates to the capacity to purchase housing. It is evident that, in order to operationalize such definitions, they require normative judgements about the cost of an acceptable standard of housing and the income that should be remaining to meet other non-housing requirements. This in itself has faced a number of criticisms [12,19,29]. 
There are two primary schools of thought on the meaning of housing affordability; one focuses on housing costs in relation to income and the other focuses on standards of housing and non-housing consumption and the income remaining once housing costs have been paid for. These ideas have fashioned two well-known and widely used affordability measures; the ratio approach and the residual measure. The residual measure is based on the notion that housing affordability is the ability of households to meet the cost of housing whilst maintaining the ability to meet other basic costs of living, i.e., the income left after paying for housing [1,13,30,33,34]; On the basis of the residual method Stone [28] developed the "shelter poverty" standard which refers to households as "shelter poor" if, after paying for housing costs, they cannot meet their non-housing needs at a socially acceptable minimum level.

The ratio approach is the traditional and most commonly accepted way to define and express housing affordability internationally [1,15-17]. However, it is apparent that the traditional approach is by no means consistently accepted among academics who have highlighted its limitations [12,18,28,29,35-38]; For example, Malpass [39] (p. 88) argues that affordability "is a virtually undefinable concept and certainly cannot be neatly or simply understood in terms of a fixed percentage of income" to be spent on housing costs. Difficulties arise in this respect because of the normative judgements required to set standards or an affordability level. Meanwhile Stone [28] (p. 6) advocates that affordability establishes the relationship between people and housing in monetary terms, but "at a deeper level affordability expresses a link between the social and economic system and the quest for the satisfaction of basic human needs that is not merely monetary”. However, the majority of affordability definitions applied and proposed still commonly focus exclusively on monetary issues related to housing. Bogdon and Can [35] criticised the pre-existing affordability literature for its focus on the price of housing rather than the condition, location and neighbourhood characteristics of the "affordable housing". This idea of affordability stretches beyond housing costs and housing standards (as emphasised earlier by [22,27]) and considers other location related attributes. Correspondingly, Belsky, et al. [36] highlight the fact that traditional approaches fail to take account of the trade-offs that households make in order to lower their housing costs, for example compromising on neighbourhood or housing quality. Stone et al. [40] (p. 2) similarly advocate that:

...affordability cannot be divorced from housing deprivation and housing standards. If a household is achieving "affordability", but only by virtue of living in overcrowded conditions, with insecure tenure or in unsafe or inaccessible locations, is that real affordability?

Such a question creates an element of subjectivity, which makes affordability a complex issue to deal with. Owing to this, the meaning of affordability will always be open to scrutiny and reinterpretation [14]. Like Stone et al. [40], Leishman and Rowley [41] argue that affordability is a wide concept that incorporates housing standards and appropriateness, economic participation and social and neighbourhood issues. Rowley and Ong [37] pose similar concerns, questioning the extent to which the quality of a neighbourhood is taken into account when assessing the appropriateness of housing that is considered as "affordable" in terms of cost. They stress that traditional indicators of housing affordability simply address the financial burden of housing costs, neglecting the fact that a household may have avoided a situation of housing stress by compromising in terms of location or housing quality. Traditional measures of affordability neglect the fact that a household may, in reality, only be able to "afford" housing in a certain location due to its lower quality or neighbourhood deprivation. Households, 
especially those on limited incomes, make trade-offs between what they desire and what they can afford to pay for housing [25]. Additional costs may be imposed on households as a result of such trade-offs, both monetary and socio-economic costs, which are disguised by traditional definitions and measures of affordability. Such costs could be detrimental to overall household wellbeing [37]. Research in Australia attempts to link the concept of affordability with environmental sustainability, arguing that "true" housing affordability must take into account, not simply rent or mortgage costs, but also a wider range of costs that households face, e.g., accessing employment, services and facilities and energy costs [42]. Likewise, Fisher et al. [18] recommend that a more thoughtful definition of affordability should consider the opportunity costs facing households due to housing location, given that the purpose of affordable housing policy should be not only to provide adequate housing but, in addition, to supply homes that are in safe areas and are accessible to jobs and decent schools. The research calls for a broader discussion and refinement of the criteria by which the suitability of affordable housing is judged, especially with respect to local amenities [18]. This is a far more holistic way to conceptualise housing affordability — having regard for quality of life and wellbeing - as opposed to simply focusing on the financial issues that face households.

While researchers in the academic environment are beginning to have wider consideration for the factors that influence housing affordability, it is important to consider how the concept of affordability is perceived by low and moderate income families themselves; are these wider notions of affordability important outside of academic or expert opinion? Seelig and Phibbs [43] conducted qualitative analysis of housing affordability in order to appreciate how low-income renters understand affordability. They found that low-income families often did not choose to live in the lowest cost housing if it presented poor options in terms of amenity and location. Thus, while cost was an essential consideration, addressing needs or preferences for dwelling features, location or proximity to services and facilities was a priority for many low income renters, even though such choices resulted in tighter household budgets and paying more for housing [43]. The research demonstrates that an array of attributes, in addition to purely economic factors, can influence a household's perception of affordability. Specifically, housing quality, location and access to services and facilities appear to be important considerations directly related to a household's opinion of housing affordability.

Despite these findings, policy environments and recent research often continue to focus on economic criteria alone as the basis of housing affordability assessments [11,17,44,45], with little regard for what households get in return for what they spend on housing. Literature proposes that there is an increasing need to gain a more encompassing understanding of housing affordability [14,18,25]. Housing affordability is not a one-dimensional concept and should not be analysed using just one concept, measure or definition [46,47]. To assist in creating more affordable and also more sustainable communities the authors also postulate that it is important to move away from defining housing affordability as a purely monetary issue. Providing affordable housing is not simply about cheap and decent homes, there must be consideration for a broader range of factors that influence households and their quality of life. If participants in the housing market were to begin thinking in a different way about affordability then considerable positive effects on households and communities could be derived [48]. The literature highlights a need to reconsider the way housing affordability is conceptualised. The researchers and other parties interested in housing development are ultimately aiming to develop a model for the assessment of a broader concept of housing affordability that is more aligned with sustainability 
concerns and household wellbeing [49-52], for which, the term "sustainable housing affordability" has been proposed recently [53].

One of the intentions of this research is to better align the traditional notion of housing affordability (i.e., the ability to pay) with more qualitative aspects and the sustainable communities concept. It may appear that the presented "sustainable housing affordability" concept is similar to that of "sustainable communities". Therefore, the line between these two terms ("affordability" and "sustainable communities") becomes blurred, and that is the intention. However, "sustainable communities" is a much broader concept that generally refers to interacting localities and neighbourhoods that promote sustainable living for present and future generations. Sustainable communities are sensitive to their environment, contribute to a high quality of life, provide opportunity and choice and meet the diverse needs of existing and future residents [54]. Accordingly, sustainable communities include broad components relating to the overall governance of communities, consideration of the needs of future generations, environmental considerations and supporting social and economic prosperity. In comparison to "housing affordability" or "sustainable communities", "sustainable housing affordability" is a concept that focuses on a households' situation; it amalgamates specific economic factors directly related to a housing affordability (i.e., the mortgage market, income and housing costs, availability of different housing tenures), along with the social (quality of life and aspects of community sustainability) and environmental factors (e.g., energy efficiency of housing), which directly relate to household well-being. It ultimately encompasses both the positive and negative monetary (such as housing costs, income, the mortgage market) and non-monetisable outcomes (such as quality, housing availability, and location trade-offs) of a household's decision to consume housing in a certain area; each of those labels - monetary and non-monetary_encompass a number of different criteria.

\section{Methods}

\subsection{Literature Review and Exploratory Interviews}

Literature review and six exploratory interviews, with senior housing policy and planning professionals in the UK, were carried out to identify the potential criteria which contribute to sustainable housing affordability. Further literature review and qualitative data collection were used to establish a comprehensive set of criteria.

\subsection{Questionnaire-Based Survey}

The questionnaire was compiled using Bristol Online Surveys (BOS) and was circulated across all regions of the UK amongst housing and planning professionals working in six different sectors including developers, housing associations, affordable housing consultants, local authority planners, housing services in local authorities and those working in urban regeneration. It was sent to a total of 600 professionals. The survey proposed a mixture of nominal and ordinal questions. Initially the survey asked background questions to create filters in order to allow for comparisons between different groups opinions on criteria importance, such as age, gender, sector of housing industry and region of the UK the professional is based. 
Subsequently, an ordinal scale of measurement was proposed to determine the level of importance of each sustainable housing affordability criterion. Each criterion was rated using a 10-point scale which ranged from $1=$ "not important at all" to $10=$ "most important" and represented importance to sustainable housing affordability from the perspective of the housing stakeholders.

\subsection{Statistical Tests Used for Questionnaire Data Analysis}

In order to facilitate the choice of a statistical test to analyse the data it was necessary to consider a number of factors. In order to test if there are statistically significant differences between groups, it is essential to first establish if the data follows a normal (Gaussian) distribution. If the data follows a normal distribution pattern then parametric tests are appropriate for statistical analysis. However, if the data is not normally distributed then less powerful non-parametric tests, or distribution-free methods, ought to be adopted in order to maintain the validity and accuracy of the data [55]. It is also important to classify variables according to their level or scale of measurement. There are certain statistical analyses which are only meaningful for data which are measured at certain measurement scales (i.e., nominal, ordinal, interval or ratio). As well as these factors, the appropriate method for statistical analysis depends on another criterion - the number of groups (two versus more than two) involved in the comparison (Table 1).

Table 1. Summary of data analysis required for this study.

\begin{tabular}{|c|c|c|c|}
\hline Data Type & $\begin{array}{l}\text { Parametric vs. } \\
\text { non-Parametric }\end{array}$ & No of Groups & $\begin{array}{c}\text { Appropriate } \\
\text { Test }\end{array}$ \\
\hline $\begin{array}{l}\text { - Ordinal scale of } \\
\text { measurement }\end{array}$ & \multirow{3}{*}{$\begin{array}{l}\text { Non-parametric } \\
\text { test required }\end{array}$} & $\begin{array}{c}\text { Comparing } \\
\text { differences between } \\
2 \text { groups } \\
\end{array}$ & $\begin{array}{c}\text { Mann Whitney } \\
\text { U test }\end{array}$ \\
\hline $\begin{array}{l}\text { - Data is not normally } \\
\text { distributed }\end{array}$ & & \multirow{2}{*}{$\begin{array}{c}\text { Comparing } \\
\text { differences between } \\
3+\text { groups }\end{array}$} & \multirow{2}{*}{$\begin{array}{c}\text { Kruskal-Wallis } \\
\text { H test }\end{array}$} \\
\hline - Independent groups & & & \\
\hline
\end{tabular}

After considering the aforementioned factors in relation to the data obtained for this study, the following statistical tests were deemed appropriate to analyse the survey data and were conducted using IBM SPSS Statistics 17 package:

- Central tendency tests - to determine average ratings of criteria importance;

- Kolmogorov-Smirnov test - to identify whether the data are normally distributed. The test was conducted on the data and each variable produced a significance value of $p<0.05$, meaning that further statistical analysis to understand differences between variables had to be non-parametric;

- Mann-Whitney U test - to identify if any significant differences exist between two groups' opinion on criteria importance;

- Kruskal Wallis test - to identify if any significant differences exist between three or more groups' opinion on criteria importance. The Mann-Whitney U test was subsequently used as a post hoc analysis on significant results. 
Non-parametrical Mann-Whitney $U$ and Kruskal Wallis statistical tests were used with the aim to establish if professional opinions on the importance of 20 sustainable housing affordability criteria differed depending on variables such as the business sector of the professional and their UK region. The following research questions were established:

- Does opinion on criteria importance differ depending on the region of the UK in which the expert is based (e.g., South East)?

- Does opinion on criteria importance differ depending on the respondent's involvement in particular sector of housing industry (e.g., housing association)?

\section{Results}

A set of criteria which could be used to represent "sustainable housing affordability" were initially established via a combination of literature review and six exploratory interviews carried out with senior housing policy and planning professionals in (Table 2).

Table 2. Comprehensive set of criteria contributing to sustainable housing affordability.

\begin{tabular}{ccc}
\hline Criteria & Sustainable Housing Affordability Criteria & $\begin{array}{c}\text { Where Criteria Derived from } \\
\text { (Literature References, Interviews) }\end{array}$ \\
\hline C1 & House prices in relation to income & {$[17,56]$ and local authority interviews } \\
\hline C2 & Rental costs in relation to income & {$[17,56]$ and local authority interviews } \\
\hline C3 & Interest rates and mortgage availability & {$[57,58]$ and local authority interviews } \\
\hline C4 & Availability of rented accommodation (private and social) & {$[59-62]$} \\
\hline C5 & Availability of low cost home ownership products & {$[59-62]$} \\
\hline C6 & Availability of market value home ownership products & {$[60-63]$} \\
\hline C7 & Safety (crime) & {$[18,60,61,64]$} \\
\hline C8 & Access to employment & {$[18,60,61,64]$} \\
\hline C9 & Access to public transport & {$[49,56,60,61,64]$} \\
\hline C10 & Access to good quality schools & {$[18,56,60,64-66]$} \\
\hline C11 & Access to shopping facilities & {$[60,64-66]$} \\
\hline C12 & Access to health services & {$[56,60,64,66]$} \\
\hline C13 14 & Access to early years child care & {$[60,64]$} \\
\hline C15 & Access to leisure facilities & {$[60,64]$} \\
\hline C16 & Access to open green public space & {$[56,59-61,64,66]$} \\
\hline C17 & Low presence of environmental problems & {$[56,59-61]$} \\
\hline C18 & Quality of housing & {$[35-37,40,41,59,61,67]$ and } \\
& local authority interviews \\
\hline C19 & Energy efficiency of housing & {$[42,59,61,68]$ and local } \\
C20 & Waste management & {$[59-61]$} \\
\hline
\end{tabular}




\subsection{Participation in Questionnaire-Based Survey}

The questionnaire was distributed to 600 professionals at management level working within different sectors of the housing industry (Figure 1). Three hundred and thirty seven responses were obtained, giving a response rate of $56 \% .51 \%$ of the survey respondents were male and $49 \%$ were female. The age of the survey respondents is shown in Figure 2. Furthermore, the region of the UK in which the respondents were based in is shown in Figure 3. To provide some background to Figure 1, "Housing Associations" are private, non-profit making organisations that provide social housing (including government-owned council housing and other affordable accommodation) for people in need of a home. "Local Authority Planning" are those working in local authorities (public sector) exercising statutory town planning functions, to manage the development of land and buildings, for a particular area. Those in the "Local Authority Housing" sector also work in local authorities (public sector) but are involved in a broad range of issues such as strategic housing activity, assessing current and future need for affordable housing and demand for market housing and assessing the condition and quality of the housing stock in the social and private sectors. The "Urban Regeneration" sector work in the public or private sector, or often public-private partnerships, and focus on the renewal of substandard city areas to reverse decline and often to create sustainable communities. "Housing Developers" generally work in the private sector to acquire buildings or land in order to construct/refurbish housing projects for sale or rent in order to generate a profit. "Property/Affordable Housing Consultants" provide consultancy advice to the housing sector and developers on aspects of new housing provision, for example on the planning and development process, development viability appraisals and economic viability assessments for affordable housing. While "Government Organisation" may include other public sector roles related to housing that are outside of local authorities, such as those working in the Department for Communities and Local Government who help local authorities and developers work with local communities to plan and build places to live and work.

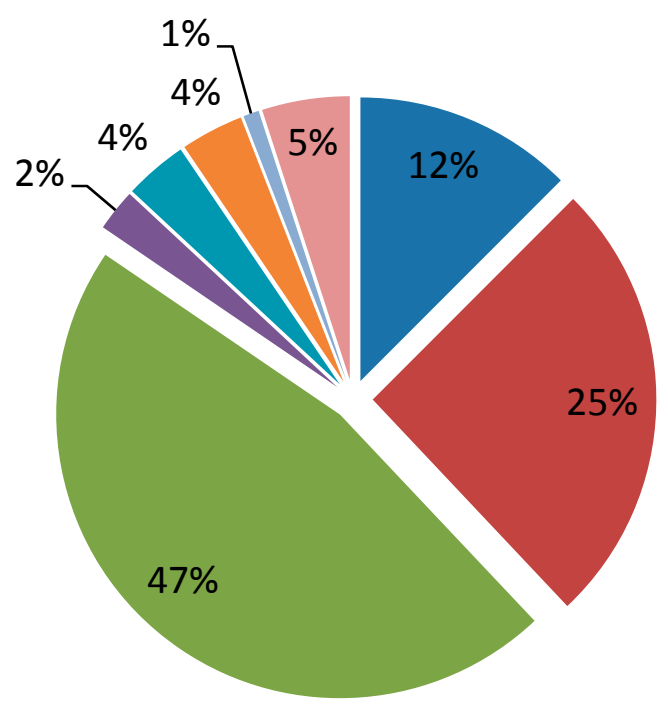

Housing association

- Local authority - planning

Local authority - housing services

- Urban regeneration

- Housing developer

$\square$ Property/Affordable Housing

Consultant

- Government organization

- Other

Figure 1. Respondent's sector of housing industry. 


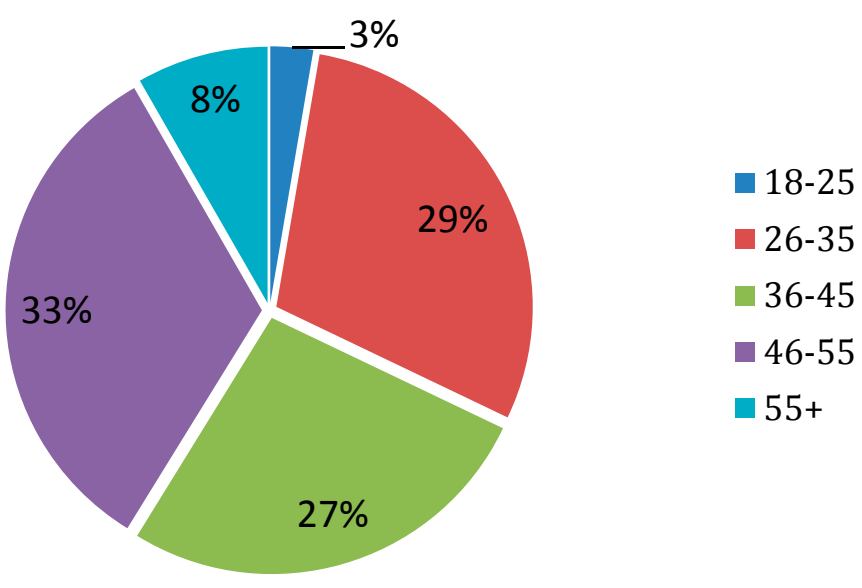

Figure 2. Age profile of survey respondents.

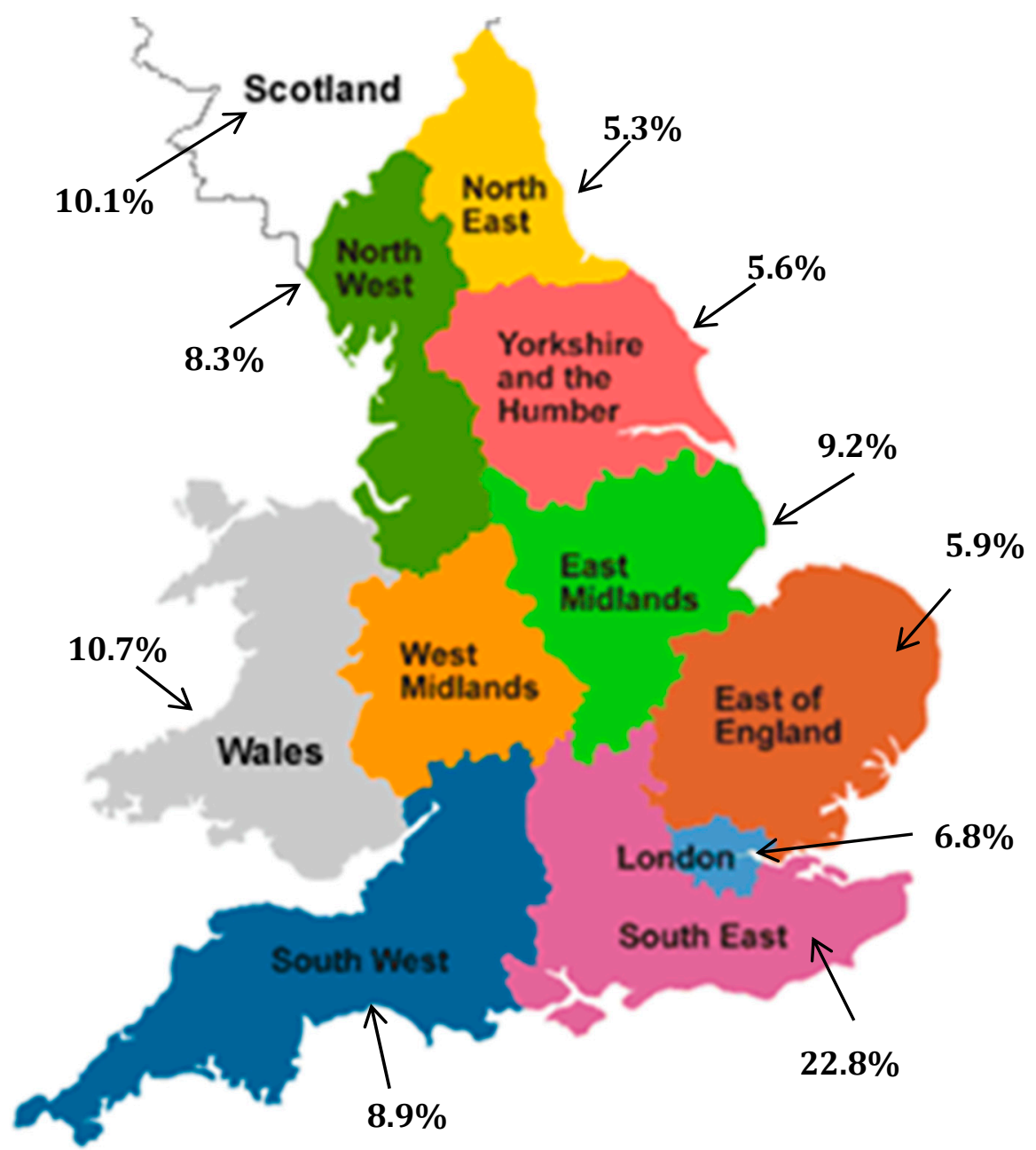

Figure 3. Distribution of respondents according to business location in different UK regions.

\subsection{Importance of Sustainable Housing Affordability Criteria in the View of Housing Stakeholders}

Descriptive statistics were used to determine the importance/significance of the 20 sustainable housing affordability criteria listed in Table 2 . The mean score of importance was calculated for each criterion (Figure 4). 


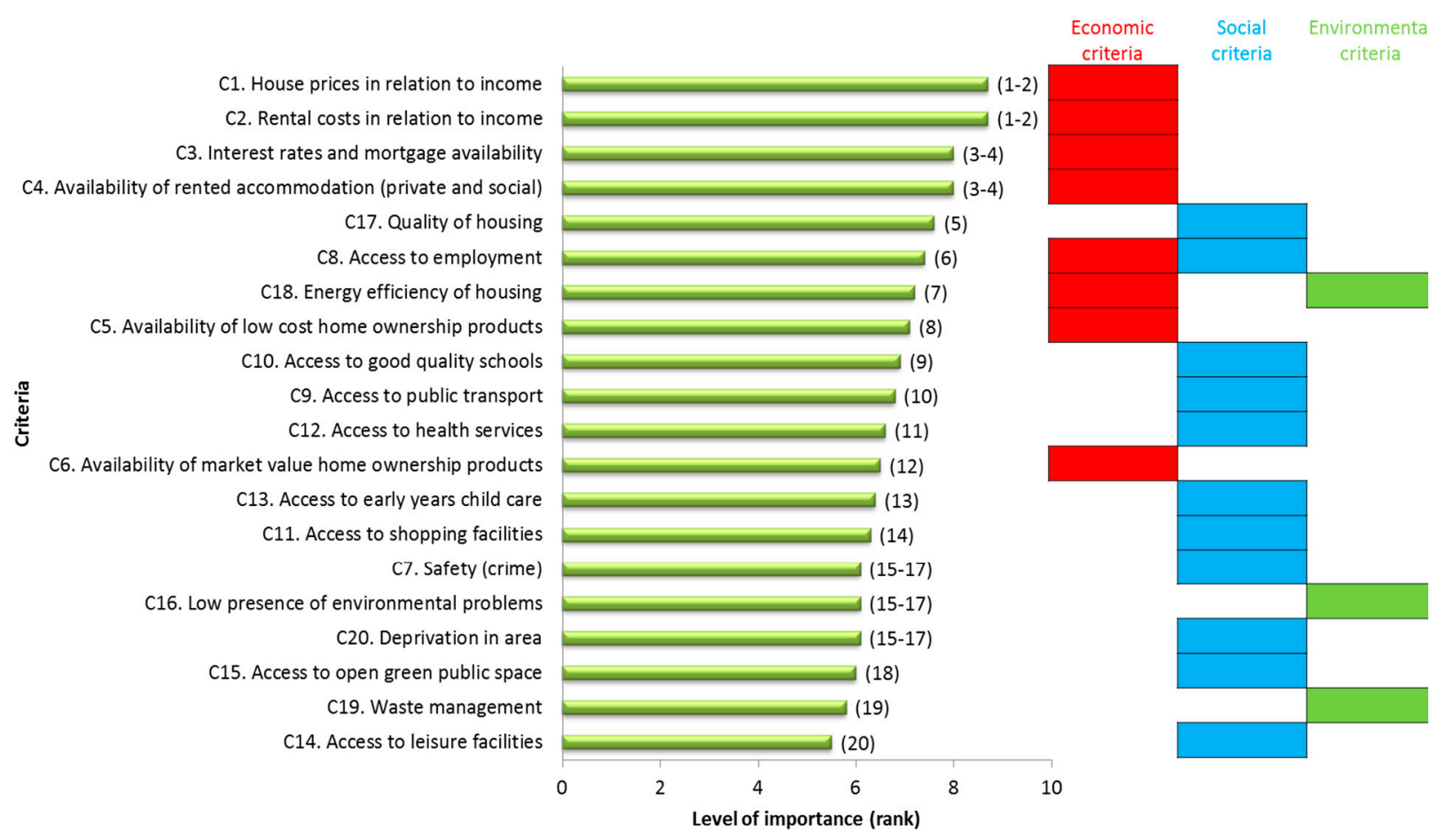

Figure 4. Mean scores of importance for sustainable housing affordability criteria.

In terms of the overall rank order of the criteria, the results reveal that the housing stakeholders perceived "house prices in relation to income" $\left(C_{1}\right)$ and "rental costs in relation to income" $\left(C_{2}\right)$ to be the most important criteria, ranking equally as 1 st and 2 nd. This was expected given that housing affordability is habitually defined by the ratio approach [1,17]. Criteria "Interest rates and mortgage availability" $\left(C_{3}\right)$ along with "availability of rented accommodation (private and social)" $\left(C_{4}\right)$ were ranked equally as $3 \mathrm{rd}$ and 4 th. It is not at all surprising that these four economic-related criteria were rated highest overall considering that affordability is habitually defined and assessed by financial attributes) $[1,16,17]$. Interestingly, the "availability of rented accommodation" $\left(C_{4}\right)$ was rated at very high level of importance. This could reflect the growth of the rented sector in the UK, especially for the younger generation who have found it difficult to access owner-occupation since the recession [70]. In comparison to this, other economic criteria such as "access to employment" $\left(C_{8}\right)$, "availability of low cost home ownership products" $\left(C_{5}\right)$ and "availability of market value home ownership products" $\left(C_{6}\right)$ were ranked as 6th, 8 th, 12th, respectively. The higher importance placed on a choice of affordable tenure options was also raised by, for example, Pittini [71] who stresses that the affordability problem can be exasperated if there is a lack of tenure choice and this can also impact on the stability of housing markets and therefore of the whole economy. Access to employment has received a high rank order in comparison to access to other amenities and facilities which supports views shared by other authors [18,37,42], who stress the importance of housing that has good accessibility to jobs, especially since this will have a direct impact on household income. "Quality of housing" $\left(\mathrm{C}_{17}\right)$ was ranked as the 5th most important criterion to sustainable housing affordability, confirming the importance of having, not only low-cost housing, but also decent standard housing. This is in conformity with researchers who advocate the importance of considering housing condition and quality in relation to affordability [30,35-37,40,41]. A number of researchers, such as [18,35-37] stressed the need to consider location related attributes such as local 
amenities and facilities in relation to housing affordability. Criteria representing access to key services and facilities (represented by $C_{9}, C_{10}, C_{11}, C_{12}, C_{13}, C_{14}$ and $C_{15}$ ) were perceived to be of middle or low importance to sustainable housing affordability by the respondents in this study. While such criteria were not perceived to be as important as economic factors and housing quality, the findings do show that they are considered to be important to some extent by the professional respondents, particularly access to schools and public transport which coincides with research undertaken by $[18,42,48,72]$. The environmental and economic criterion "energy efficiency of housing" $\left(C_{18}\right)$ was rated fairly high in 7 th position, indicating the significance of providing affordable housing that is also sustainable by design. This supports the views of other authors $[43,60,69]$ who highlight the importance of energy efficient housing, especially given the increase in expenditure on domestic energy consumption and the widespread phenomenon of energy poverty in the EU [71]. "Safety" $\left(C_{7}\right)$, "presence of environmental problems" $\left(C_{16}\right)$ and "deprivation in area" $\left(C_{20}\right)$ were ranked as 15 th, 16th and 17 th. "Access to leisure facilities" $\left(C_{14}\right)$ was rated as the least important criterion overall, with "Availability of waste management facilities" $\left(C_{19}\right)$ scoring only slightly higher. Perhaps the translation and acceptance of the importance of such criteria to affordability, which are more "qualitative", will be slower in industry/policy environments than for the academic environment. In some respects this confirms Stone's [20] view that academic and policy environments may be inconsistent with the notion of affordability.

\subsection{Professional Perceptions Depending on the UK Geographical Region and Sector of Housing Industry}

The Kruskal-Wallis test was used to compare for differences between groups in order to answer the questions detailed in Table 3.

Table3. Research questions.

\begin{tabular}{cc}
\hline Groups Compared & Research Question \\
\hline UK region of housing industry & $\begin{array}{c}\text { Does opinion on criteria importance differ depending on } \\
\text { the region of the UK in which the expert is based? }\end{array}$ \\
\hline Sector of housing industry & $\begin{array}{c}\text { Does opinion on criteria importance differ depending on the } \\
\text { respondent's involvement in a particular sector of the housing industry? }\end{array}$ \\
\hline
\end{tabular}

\subsubsection{UK Region of Housing Industry}

In order to identify if the respondents' particular location of housing industry within the UK had any influence on the rankings of criteria importance given, the Kruskal-Wallis test was conducted. Respondents were assigned to one of the $11 \mathrm{UK}$ regions (UK regions and response rate from each region are shown in Figure 3). Results revealed that there was a statistically significant difference between the UK regions for the following criteria:

- $\quad C_{4}$ "availability of rented accommodation" $(H(10)=18.799, p=0.043)$ at $p<0.05$;

- $C_{13}$ "access to early years child care" $(H(10)=19.506, p=0.034)$ at $p<0.05$.

In order to identify which particular region of employment groups differed, a post hoc Mann Whitney test was conducted on the two significant criteria. Using the formula $\mathrm{k}(\mathrm{k}-1) / 2$, where 
$\mathrm{k}$ is the number of groups, the number of comparisons required for the post hoc Mann-Whitney test was determined:

- Number of comparisons required: $11(11-1) / 2=55$

- Bonferroni adjustment: 0.05/55=0.0009 (new alpha level)

After conducting post hoc Mann Whitney tests on $C_{4}$ and $C_{13}$, no significant results were found between UK regions at the new alpha level of 0.0009. This suggests that professionals in different regions of the UK have fairly consistent opinions of criteria importance. This confirms that the importance of the criteria established can be deemed equally relevant for all regions within the UK if such a system of criteria is used in further research.

\subsubsection{Sector of Housing Industry}

The difference in the average rankings of criteria importance depending on the respondent's particular sector of the housing industry is visible in Table 4 . The overall average rank order of the criteria is shown in the "ranking of criteria column"; this can be compared to the average rank obtained by each sector which is represented by the green shading (the highest rank/importance is represented by the lightest shade and the lowest rank/importance is represented by the darkest shade). The standard deviation is provided in brackets below the average rankings by each sector to show the level of variability in the scores.

Table 4. Comparison of criteria importance by sectors.

\begin{tabular}{|c|c|c|c|c|c|c|c|c|c|}
\hline \multirow{2}{*}{\multicolumn{2}{|c|}{$\begin{array}{l}\text { Sustainable housing } \\
\text { affordability criteria }\end{array}$}} & \multirow{4}{*}{$\begin{array}{c}\begin{array}{c}\text { Ranking } \\
\text { of criteria }\end{array} \\
1\end{array}$} & \multicolumn{7}{|c|}{$\begin{array}{l}\text { Average level of criteria importance by sector } \\
\text { (with standard deviation in brackets) }\end{array}$} \\
\hline & & & \multirow{2}{*}{$\begin{array}{c}\text { HA } \\
8.6 \\
\end{array}$} & \multirow{2}{*}{$\begin{array}{c}\text { LA-P } \\
8.8 \\
\end{array}$} & \multirow{2}{*}{$\begin{array}{c}\text { LA-HS } \\
8.9 \\
\end{array}$} & \multirow{2}{*}{$\begin{array}{c}\text { UR } \\
8 \\
\end{array}$} & \multirow{2}{*}{$\begin{array}{c}\text { HD } \\
7.4 \\
\end{array}$} & \multirow{2}{*}{$\begin{array}{c}\text { PAHC } \\
9.4 \\
\end{array}$} & \multirow{2}{*}{$\begin{array}{r}\text { GO } \\
7.3 \\
\end{array}$} \\
\hline $\mathrm{C}_{1}$ & House prices in relation & & & & & & & & \\
\hline$C 1$ & to income & & $(1.76)$ & $(1.68)$ & $(1.21)$ & (1.6) & $(2.47)$ & $(1.17)$ & $(0.58)$ \\
\hline \multirow{2}{*}{$\mathrm{C} 2$} & \multirow{2}{*}{$\begin{array}{l}\text { Rental costs in relation to } \\
\text { income }\end{array}$} & \multirow{2}{*}{1} & 8.8 & 8.6 & 8.8 & 8.5 & 6.9 & 9.3 & 7.3 \\
\hline & & & $(1.25)$ & $(1.56)$ & $(1.19)$ & $(1.69)$ & $(2.50)$ & $(1.06)$ & $(0.58)$ \\
\hline \multirow{2}{*}{$\mathrm{C} 3$} & \multirow{2}{*}{$\begin{array}{l}\text { Interest rates and } \\
\text { mortgage availability }\end{array}$} & \multirow{2}{*}{3} & 8.1 & 7.8 & 8.2 & 7.3 & 7.6 & 8.5 & 7 \\
\hline & & & $(1.64)$ & $(1.83)$ & $(1.42)$ & $(1.98)$ & $(2.71)$ & $(1.24)$ & $(0)$ \\
\hline \multirow[b]{2}{*}{$\mathrm{C} 4$} & \multirow{2}{*}{$\begin{array}{l}\text { Availability of rented } \\
\text { accommodation (private } \\
\text { and social) }\end{array}$} & \multirow[b]{2}{*}{3} & 8.3 & 7.6 & 8.3 & 7.5 & 6.7 & 7.8 & 8.7 \\
\hline & & & $(1.7)$ & (1.6) & $(1.41)$ & $(0.93)$ & $(2.61)$ & $(1.8)$ & $(0.58)$ \\
\hline \multirow{2}{*}{$\mathrm{C} 17$} & \multirow{2}{*}{ Quality of housing } & \multirow{2}{*}{5} & 8 & 7.4 & 7.9 & 8 & 6.4 & 6.5 & 7.3 \\
\hline & & & $(1.7)$ & $(1.88)$ & $(1.71)$ & $(1.31)$ & $(2.68)$ & $(1.45)$ & $(1.53)$ \\
\hline \multirow{2}{*}{$\mathrm{C} 8$} & \multirow{2}{*}{ Access to employment } & \multirow{2}{*}{6} & 8 & 7.2 & 7.4 & 7.9 & 7.3 & 6.5 & 7.7 \\
\hline & & & $(1.59)$ & $(1.78)$ & $(1.77)$ & $(1.25)$ & $(2.43)$ & $(1.88)$ & $(3.22)$ \\
\hline \multirow{2}{*}{$\mathrm{C} 18$} & \multirow{2}{*}{$\begin{array}{l}\text { Energy efficiency of } \\
\text { housing }\end{array}$} & \multirow{2}{*}{7} & 7.6 & 7 & 7.4 & 7.6 & 6.5 & 5.9 & 6.7 \\
\hline & & & $(1.95)$ & $(2.11)$ & $(1.78)$ & $(1.77)$ & (3.09) & $(2.19)$ & $(0.58)$ \\
\hline
\end{tabular}


Table 4. Cont.

\begin{tabular}{|c|c|c|c|c|c|c|c|c|c|}
\hline \multirow{2}{*}{\multicolumn{2}{|c|}{$\begin{array}{l}\text { Sustainable housing } \\
\text { affordability criteria }\end{array}$}} & \multirow{2}{*}{$\begin{array}{l}\text { Ranking } \\
\text { of criteria }\end{array}$} & \multicolumn{7}{|c|}{$\begin{array}{c}\text { Average level of criteria importance by sector } \\
\text { (with standard deviation in brackets) }\end{array}$} \\
\hline & & & HA & LA-P & LA-HS & UR & HD & РАНC & GO \\
\hline \multirow[b]{2}{*}{$\mathrm{C} 5$} & \multirow{2}{*}{$\begin{array}{l}\text { Availability of low cost } \\
\text { home ownership } \\
\text { products }\end{array}$} & \multirow[b]{2}{*}{8} & 6.8 & 6.9 & 7 & 6.8 & 6.9 & 7.4 & 7.3 \\
\hline & & & $(2.03)$ & (1.99) & $(1.81)$ & $(1.58)$ & $(2.47)$ & $(2.11)$ & $(2.08)$ \\
\hline \multirow{2}{*}{$\mathrm{C} 10$} & \multirow{2}{*}{$\begin{array}{l}\text { Access to good quality } \\
\text { schools }\end{array}$} & \multirow{2}{*}{9} & 7.7 & 6.8 & 6.8 & 8.1 & 6.8 & 6 & 7.3 \\
\hline & & & $(1.81)$ & $(2.07)$ & $(1.79)$ & $(1.55)$ & $(2.45)$ & $(1.60)$ & $(2.08)$ \\
\hline \multirow{2}{*}{ C9 } & \multirow{2}{*}{$\begin{array}{l}\text { Access to public } \\
\text { transport }\end{array}$} & \multirow{2}{*}{10} & 7.5 & 6.9 & 6.6 & 6.8 & 6.3 & 6.1 & 6.7 \\
\hline & & & $(1.81)$ & $(1.97)$ & $(1.76)$ & $(2.38)$ & $(2.38)$ & $(2.02)$ & $(2.31)$ \\
\hline \multirow{2}{*}{$\mathrm{C} 12$} & \multirow{2}{*}{ Access to health services } & \multirow{2}{*}{11} & 7.1 & 6.7 & 6.4 & 7.6 & 5.4 & 5.3 & 7 \\
\hline & & & $(1.86)$ & $(1.92)$ & $(1.86)$ & $(1.69)$ & $(2.28)$ & $(1.91)$ & $(2)$ \\
\hline \multirow[b]{2}{*}{ C6 } & \multirow{2}{*}{$\begin{array}{l}\text { Availability of market } \\
\text { value home ownership } \\
\text { products }\end{array}$} & \multirow[b]{2}{*}{12} & 6.7 & 6.4 & 6.5 & 6 & 6 & 7.6 & 7 \\
\hline & & & $(1.76)$ & $(2.19)$ & $(1.84)$ & $(1.41)$ & $(2.17)$ & $(1.31)$ & (2) \\
\hline \multirow{2}{*}{$\mathrm{C} 13$} & \multirow{2}{*}{$\begin{array}{l}\text { Access to early years } \\
\text { child care }\end{array}$} & \multirow{2}{*}{13} & 7 & 6.5 & 6.1 & 7.6 & 5.8 & 5.3 & 6.3 \\
\hline & & & $(1.97)$ & $(1.85)$ & $(1.8)$ & $(1.92)$ & $(2.3)$ & $(1.83)$ & $(2.08)$ \\
\hline \multirow{2}{*}{$\mathrm{C} 11$} & \multirow{2}{*}{$\begin{array}{l}\text { Access to shopping } \\
\text { facilities }\end{array}$} & \multirow{2}{*}{14} & 6.9 & 6.5 & 6 & 7.4 & 5.1 & 5.3 & 6.3 \\
\hline & & & $(2.02)$ & $(1.85)$ & $(1.72)$ & $(1.92)$ & $(2.5)$ & $(2.02)$ & $(1.53)$ \\
\hline \multirow{2}{*}{$\mathrm{C} 7$} & \multirow{2}{*}{ Safety (crime) } & \multirow{2}{*}{15} & 6.9 & 5.6 & 6.1 & 7 & 5.5 & 5 & 6.7 \\
\hline & & & $(2.16)$ & $(2.19)$ & $(1.92)$ & $(1.6)$ & $(3.06)$ & $(2.13)$ & $(2.31)$ \\
\hline \multirow{2}{*}{$\mathrm{C} 16$} & \multirow{2}{*}{$\begin{array}{l}\text { Low presence of } \\
\text { environmental problems }\end{array}$} & \multirow{2}{*}{15} & 6.5 & 5.8 & 6.1 & 7.3 & 5.7 & 5.1 & 7 \\
\hline & & & $(2.11)$ & $(2.07)$ & $(1.89)$ & $(1.49)$ & $(2.19)$ & $(1.93)$ & $(1.93)$ \\
\hline C20 & Denrivation in area & 15 & 6.9 & 5.3 & 6.3 & 5.6 & 6 & 5.8 & 6.3 \\
\hline-20 & Depitvationit in alca & 10 & $(1.97)$ & $(2.3)$ & $(2.01)$ & $(2.33)$ & $(2.13)$ & $(1.75)$ & $(1.16)$ \\
\hline$C 15$ & Access to open green & 18 & 6.1 & 6.3 & 5.8 & 7.1 & 5.3 & 5.2 & 6 \\
\hline C12 & public space & 10 & $(2.16)$ & $(1.99)$ & $(1.99)$ & $(1.89)$ & $(2.31)$ & $(1.95)$ & $(1.73)$ \\
\hline C19 & Waste management & 19 & 6.2 & 5.6 & 5.8 & 6.5 & 5.6 & 5.3 & 6.3 \\
\hline & & 17 & $(2.49)$ & $(2.34)$ & $(2.04)$ & $(2.45)$ & $(2.94)$ & $(2.53)$ & $(2.52)$ \\
\hline $\mathrm{C} 14$ & Access to leisure & 20 & 5.7 & 6 & 5.2 & 7.5 & 4.9 & 5.1 & 5.7 \\
\hline-14 & facilities & 20 & $(2.04)$ & $(1.97)$ & $(1.95)$ & $(1.85)$ & $(2.31)$ & $(1.93)$ & $(1.53)$ \\
\hline
\end{tabular}

In order to identify if the differences in rankings, dependent on the respondents' particular sector of the housing industry, were statistically significant, the Kruskal-Wallis test was conducted. Respondents were assigned to one of seven sectors of housing associated industries (the response rate from each group is illustrated in Figure 3). Results showed that there was a statistically significant difference between groups' ratings of criteria importance for 13 out of 20 criteria (significant results detailed in Table 5). Looking at the significant criteria in Table 5 and then comparing the mean rankings in Table 4, you can see, for example, that property/affordable housing consultants (PAHC) gave the highest rankings to "house prices in relation to income" $\left(C_{1}\right)$ and "rental costs in relation to income" $\left(C_{2}\right)$ compared to other sector groups. Whereas they provided fairly low rankings, in comparison to other sectors, to more qualitative criteria (such as $C_{7}, C_{9}, C_{10}, C_{11}, C_{12}, C_{14}, C_{15}, C_{16}, C_{17}, C_{18}, C_{19}$ ). This may reflect the nature of the consultant's role being highly focused on economic viability. Surprisingly housing developers (HD) gave low rankings to economic criteria $C_{1}, C_{2}$ and $C_{1}$ compared to other sector groups. In general, developer's rankings of criteria were lower than those made by other sectors, including for "quality of 
housing" $\left(C_{17}\right)$. This could be due to developers having a shorter term view of a housing product, as opposed to the other sectors which may have a longer term interest. However, overall the standard deviations on all criteria rankings by developers were higher than for other sectors, indicating more variability in their opinion on criteria importance. The government organization (GO) sector, followed by local authority housing services (LAHS) and housing associations (HA), placed high importance on "Availability of rented accommodation (private and social)" $\left(C_{4}\right)$. This may reflect the nature of their work which deals with rented accommodation (LA-HS and HA) and also the importance the government places on the rented sector and the new "affordable rent" tenure option to meet housing need in the UK [73]. It seems that those working in the urban regeneration (UR) sector placed a higher importance than other sectors on numerous criteria, such as "Low presence of environmental problems" $\left(C_{16}\right)$ and access to a range of services and facilities (represented by $C_{14}, C_{15}, C_{13}, C_{12}, C_{11}, C_{10}$ ). This could be due to such a sector having more experience with the sustainable communities' concept, which is often a necessary aspect of urban regeneration projects today [74]. Although, the UR sector had very similar rankings to the HA sector for "quality of housing" $\left(C_{17}\right)$, "access to employment" $\left(C_{8}\right)$, "energy efficiency of housing" $\left(C_{18}\right)$, "availability of low cost home ownership" $\left(\mathrm{C}_{5}\right)$ and "safety" $\left(C_{7}\right)$. It is worth noting some other similarities in the rankings of criteria, and thus consensus, by different sectors. For example, $C_{5}$ received similar rankings by HA, LA-P, LA-HS, UR and HD, whereas PAHC and GO gave slightly higher and more similar rankings to one another for this criterion. Economic criterion "house prices in relation to income" $\left(C_{1}\right)$ received similar rankings by HA, LA-P and LA-HS. Such sectors, in addition to UR, also placed similar importance on "rental costs in relation to income" $\left(C_{2}\right)$. HA and GO had comparable rankings for "access to leisure" $\left(C_{14}\right)$, "waste management" $\left(C_{19}\right)$, "access to green space" $\left(C_{15}\right)$ and "access to health" $\left(C_{12}\right)$. LA-P and LA-H had very similar ranking opinions for a number of criteria including $C_{1}, C_{2}, C_{8}, C_{5}, C_{10}, C_{6}, C_{19}$, while HDs shared such comparable rankings for $C_{1}, C_{8}, C_{5}, C_{10}$. HD and LA-P also had similarity in opinion for $C_{19}, C_{16}, C_{7}$ and $C_{3}$.

Table 5. Significant results of Kruskal-Wallis test when comparing sectors of housing industry.

\begin{tabular}{cc}
\hline Criterion & Kruskal-Wallis Test Result \\
\hline$C_{1}:$ House prices in relation to income & $H(6)=21.821, p=0.001(p<0.01)$ \\
$C_{2}:$ Rental costs in relation to income & $H(6)=17.114, p=0.009(p<0.01)$ \\
$C_{4}:$ Availability of rented accommodation & $H(6)=18.502, p=0.005(p<0.01)$ \\
$C_{7}$ : Safety & $H(6)=14.510, p=0.024(p<0.05)$ \\
$C_{8}$ : Access to employment & $H(6)=15.032, p=0.020(p<0.05)$ \\
$C_{9}:$ Access to public transport services & $H(6)=13.190, p=0.040(p<0.05)$ \\
$C_{10}:$ Access to good quality schools & $H(6)=15.950, p=0.014(p<0.05)$ \\
$C_{11}:$ Access to shopping facilities & $H(6)=21.263, p=0.002(p<0.01)$ \\
$C_{12}:$ Access to health services & $H(6)=16.806, p=0.010(p<0.05)$ \\
$C_{13}:$ Access to early years child care & $H(6)=17.184, p=0.009(p<0.01)$ \\
$C_{14}:$ Access to leisure facilities & $H(6)=19.929, p=0.003(p<0.01)$ \\
$C_{17}:$ Quality of housing & $H(6)=17.028, p=0.009(p<0.01)$ \\
$C_{20}$ : Deprivation in area & $H(6)=19.209, p=0.004(p<0.01)$ \\
\hline
\end{tabular}

To identify which particular sectors of the housing industry differed in opinion in a statistically significant sense, a post hoc Mann Whitney test was conducted on significant criteria using the same 
approach discussed in 3.3.1.The number of comparisons required was: $7(7-1) / 2=21$. Bonferroni adjustment: 0.05/21 $=0.0024$ (new alpha/significance level).

Following post hoc Mann Whitney tests on $C_{1}$ (house prices in relation to income), $C_{2}$ (rental costs in relation to income), $C_{7}$ (safety), $C_{8}$ (access to employment), $C_{9}$ (access to public transport services), $C_{10}$ (access to good quality schools), $C_{12}$ (access to health services) and $C_{17}$ (quality of housing), no significant results were found between sectors of the housing industry at the new significance level. It needs to be mentioned that despite the low number of responses in three of the sectors (urban regeneration, housing developers and property consultants), which could be considered as a limitation of analysis, non-parametric statistical methods used in this study are most appropriate when the sample sizes are small [75]. Average levels of importance for those criteria that received statistically different scores (significance level of $p<0.0024$ ) between sectors are highlighted with a blue dashed border line in Table 4. The post hoc Mann-Whitney test revealed that for $C_{4}$ (availability of rented accommodation) there was a statistically significant difference between sectors of housing industry 2 (local authority planning) and 3 (local authority housing). Respondents working within local authority housing gave statistically significantly higher rankings of importance to the "availability of rented accommodation" compared to those working within local authority planning at sig $0.001(p<0.0024)$. This could be due to such sectors having differing policies/goals to adhere to, e.g., local authority housing seek to have more rented accommodations, while planners may be more concerned with overall contribution to housing construction, having less interest in how this is split between rented and private housing. However, you can see from Table 4 that the government organisation sector gave a higher ranking to this criterion in comparison to the local authority housing services group. Thus, the results should be treated with caution since the small sample size for some sectors could be the cause of no significant differences being found between such groups. Other statistically significant differences were associated with less important criteria, which were ranked in 14th, 15-17th and 20th positions (Table 6). Planners placed less emphasis on $C_{20}$ (deprivation) than both housing associations and local authority housing. This could perhaps be due to planners seeing the potential for new development to improve deprived areas. These findings confirm views shared by Gabriel et al. [14] that different professional interest groups may impose their own definition of the problem and conceptualise it in accordance with their own interests. Subsequently, such interest groups may seek different solutions to address the issue [14]. This also highlights the fact that the concept is open to subjective interpretations which can make it a difficult one to grapple with. Since the differences established were found between groups that had larger sample sizes, it is possible that if the sample sizes were larger for the urban regeneration, housing developers and property consultants sectors that more significant differences in opinion may have been established. 
Table 6. Significant differences in perception of criteria contributing to the sustainable housing affordability based on sector of housing industry.

\begin{tabular}{cccc}
\hline Sector of Housing Industry & Criterion & Mann-Whitney Result & Rank of Criterion \\
\hline $\begin{array}{c}\text { Local authority housing gave } \\
\text { higher rankings than local } \\
\text { authority planning }\end{array}$ & $\begin{array}{c}C_{4} \text { : availability of } \\
\text { rented accommodation }\end{array}$ & $\begin{array}{c}U=5054, Z=-3.310, \\
p=0.001(p<0.0024)\end{array}$ & 4 \\
\hline $\begin{array}{c}\text { Housing associations gave } \\
\text { higher rankings than local } \\
\text { authority housing }\end{array}$ & $\begin{array}{c}C_{11} \text { : access to } \\
\text { shopping facilities }\end{array}$ & $\begin{array}{c}U=2278, Z=-3.126, \\
p=0.002(p<0.0024)\end{array}$ & 14 \\
\hline $\begin{array}{c}\text { Local authority planning } \\
\text { gave higher rankings than } \\
\text { local authority housing }\end{array}$ & $\begin{array}{c}C_{14} \text { : access to } \\
\text { leisure facilities }\end{array}$ & $\begin{array}{c}U=5098, Z=-3.195, \\
p=0.001(p<0.0024)\end{array}$ & 20 \\
\hline $\begin{array}{c}\text { Housing associations gave } \\
\text { higher rankings than local } \\
\text { authority planning }\end{array}$ & $\begin{array}{c}C_{20} \text { : deprivation } \\
\text { in area }\end{array}$ & $\begin{array}{c}U=1074, Z=-3.751, \\
p=0.000(p<0.0024)\end{array}$ & $15-17$ \\
\hline $\begin{array}{c}\text { Local authority housing gave } \\
\text { higher rankings than local } \\
\text { authority planning }\end{array}$ & $\begin{array}{c}C_{20} \text { : deprivation } \\
\text { in area }\end{array}$ & $\begin{array}{c}U=5026, Z=-3.333, \\
p=0.001(p<0.0024)\end{array}$ & $15-17$ \\
\hline
\end{tabular}

\section{Discussion}

The quantitative research in this paper presents the analysis of 337 questionnaires, conducted with housing and planning professionals in the UK. This survey allowed the researchers to determine the importance of 20 sustainable housing affordability criteria. Research results showed that at present key stakeholders in the housing industry perceived the economic criteria, such as "house prices in relation to income", "rental costs in relation to income", "interest rates and mortgage availability" and "availability of rented accommodation" to be the most important when considering sustainable housing affordability, ranking them from 1 st to 4 th. This finding was expected given that financial attributes alone are principally used to define and measure affordability. It needs to be mentioned that the very high rank of importance (4th) of criterion "availability of rented accommodation" could reflect the current economic climate, where rental properties (both social housing and private properties) are often necessary to meet affordable housing need, since home ownership products are increasingly out of reach for many wishing to get onto the housing ladder owing to the difficulty accessing mortgage finance following the global financial crisis of 2008 [76]. However, social and more qualitative criteria such as "quality of housing" and "access to good quality schools", ranked as 5th and 9th, and environmental-economic criterion "energy efficiency of housing", ranked as 7th, are of high importance and can significantly shape decision making. It appears that housing stakeholders in the industry are recognising, at least to some extent, the importance of quality and location related attributes in line with a number of academics [18,35-37,40,41].

Given that different interest groups can struggle to impose their own definition of the concept of affordability [14], statistical analyses of the questionnaire data were conducted using non-parametric statistics with an aim to establish if there were any significant differences in perceptions between respondents; first, depending on the professionals' location (i.e., UK region) and second, on the sector of the housing industry which the professionals are employed. 
Results of the first analysis suggested that opinion on criteria importance did not change in different regions of the UK. This indicated that, on one hand, the professional views and perceptions of criteria importance were consistent across the UK, and on the other hand, criteria were rated independently of the existing economic and housing market differences between some regions of the UK (e.g., higher housing prices in South East than in other parts of England) [44]. This shows regularity of professional interpretation and assessment of issues relevant to sustainable housing affordability across the whole of the UK. Moreover, the importance of the criteria established can be deemed equally relevant for all regions within the UK if such a system of criteria is used in further research.

The second analysis showed, however, that professional perceptions on criteria importance varied to some extent depending on the sector of the housing industry that the professional is employed in. Four (20\%) out of the 20 sustainable housing affordability criteria, namely "availability of rented accommodation", "access to shopping facilities", "access to leisure facilities" and "deprivation in area" differed significantly and mainly involved differences between views of experts from local authority planning and local authority housing services.

\section{Conclusions}

This paper focuses on the concept and relevant criteria that contribute to sustainable housing affordability. As the traditional definition of housing affordability mostly focus on economic criteria alone, with little consideration for what households acquire in terms of social and environmental criteria (e.g., housing quality, neighbourhood deprivation, energy efficiency of housing, etc.), it is becoming increasingly evident that there is a need to consider the way the housing affordability is conceptualised. With this new definition of sustainable housing affordability we attempt to integrate other criteria, which arise from concepts such as housing affordability, sustainable housing and sustainable communities. Therefore, through empirical literature research and interviews with experts we establish and validate a comprehensive set of criteria by which housing affordability can be assessed more holistically by co-integrating a sustainability aspect. . The presented criteria system can provide interested parties, such as local authorities, policy makers and government, with a broader range of factors to consider in order to make more informed and sustainable decisions about the affordability of housing. The established system of criteria contributing to sustainable housing affordability will aid in developing methodologies that can be applied to assess the affordability of different housing locations in a sustainable manner. The different rankings of the criteria can be used to place levels of importance in affordable housing development and policy. It is hoped that this study will promote further research across the globe into a broader concept of affordability that is better aligned with sustainability. Additionally, a further study investigating how this criteria system for sustainable housing affordability is perceived by low and moderate income families would be valuable.

\section{Author Contributions}

Dr. Mulliner conducted the quantitative data collection and analysis and wrote the initial draft of this paper. Dr. Maliene is responsible for assisting with the revision of the paper and improving the tables/figures contained within the manuscript. Both authors have read and approved the final manuscript. 


\section{Conflicts of Interests}

The authors declare no conflict of interest.

\section{References}

1. Whitehead, C. From need to affordability: An analysis of UK housing objectives. Urban. Stud. 1991, $28,871-887$.

2. Bramley, G. Affordability, poverty and housing need: Triangulating measures and standards. J. Hous. Built Environ. 2012, 27, 133-151.

3. Chen, J.; Hao, Q.; Stephens, M. Assessing housing affordability in post-reform China: A case study of Shanghai. Hous. Stud. 2010, 25, 877-901.

4. Crook, A.D.H.; Monk, S.; Rowley, S.; Whitehead, C.M.E. Planning gain and the supply of new affordable housing in England-Understanding the numbers. Town Plan. Rev. 2006, 77, 353-373.

5. Gurran, N.; Phibbs, P. Housing supply and urban planning reform: The recent Australian experience 2003-2012. Int. J. Hous. Policy 2013, 13, 381-407.

6. Haffner, M.; Boumeester, H. Housing affordability in the Netherlands: The impact of rent and energy costs. J. Hous. Built Environ. 2014, 25, 799-820.

7. Moore, E.; Skaburskis, A. Canada's increasing housing affordability burdens. Hous. Stud. 2004, 19, 395-413.

8. Mulliner, E.; Maliene, V. Austerity and reform to affordable housing policy. J. Hous. Built Environ. 2013, 28, 397-407.

9. Norris, M.; Shiels, P. Housing affordability in the republic of Ireland: Is planning part of the problem or part of the solution? Hous. Stud. 2007, 22, 45-62.

10. Yates, J. Australia's housing affordability crisis. Aust. Econ. Rev. 2008, 41, 200-214.

11. Gan, Q.; Hill, R.J. Measuring housing affordability: Looking beyond the median. J. Hous. Econ. 2009, 18, 115-125.

12. Hulchanski, J.D. Discrimination in Ontario's Rental Housing Market: The Role of Minimum Income Criteria; Ontario Human Rights Commission: Toronto, ON, Canada, 1994.

13. Stone, M.E. What is housing affordability? The case for the residual income approach. Hous. Policy Debate 2006, 17, 151-184.

14. Gabriel, M.; Jacobs, K.; Arthurson, K.; Burke, T.; Yates, J. Conceptualising and Measuring the Housing Affordability Problem, National Research Venture 3: Housing Affordability for Lower Income Australians; Australian Housing and Urban Research Institute: Melbourne, Australia, 2005.

15. Kutty, N.K. A New Measure of Housing Affordability: Estimates and Analytical Results. Hous. Policy Debate 2005, 16, 113-142.

16. Lux, M. The quasi-normative approach to housing affordability: The case of the Czech Republic. Urban Stud. 2007, 44, 1109-1124.

17. Whitehead, C.; Monk, S.; Clarke, A.; Holmans, A.; Markkanen, S. Measuring Housing Affordability: A Review of Data Sources; Cambridge Centre for Housing and Planning Research: Cambridge, UK, 2009. 
18. Fisher, L.M.; Pollakowski, H.O.; Zabel, J. Amenity-based housing affordability indexes. Real Estate Econ. 2009, 37, 705-746.

19. Bramley, G. An affordability crisis in British housing: Dimensions, causes and policy impact. Hous. Stud. 1994, 9, 103-124.

20. Stone, M.E. Housing Affordability: One-Third of a Nation Shelter Poor. In Right to Housing: Foundation for a New Social Agenda; Bratt, R., Stone, M.E., Hartman, C.A., Eds.; Temple University Press: Philadelphia, PA, USA, 2005; pp. 38-60.

21. Hulchanski, J.D. The concept of housing affordability: Six contemporary uses of the housing expenditure-to-income ratio. Hous. Stud. 1995, 10, 471-491.

22. MacLennan, D.; Williams, R. Affordable Housing in Britain and America; Joseph Rowntree Foundation: England, UK, 1990.

23. Linneman, P.; Megbolugbe, I.F. Housing Affordability: Myth or Reality? Urban. Stud. 1992, 29, 369-392.

24. Malpass, P.; Murie, A. Housing Policy and Practice; Macmillan Press Ltd.: London, UK, 1990.

25. Ndubueze, O. Measuring Housing Affordability: A composite approach. In Proceedings of the ENHR 2007 International Conference Sustainable Urban Areas, Rotterdam, The Netherlands, 25-28 June 2007.

26. Quigley, J.M.; Raphael, S. Is Housing Unaffordable? Why Isn't It More Affordable? J. Econ. Perspect. 2004, 18, 191-214.

27. Bramley, G. Access, affordability and housing need. In Proceedings of the ESRC Housing Studies Conference, University of Surrey, Bristol, SAUS, University of Bristol, September 1990.

28. Stone, M.E. Shelter Poverty: New Ideas on Housing Affordability; Temple University Press: Philadelphia, PA, USA, 1993.

29. Hancock, K.E. Can pay? Won't Pay? or Economic Principles of “affordability”. Urban. Stud. 1993, 30, 127-145.

30. Chaplin, R.; Martin, S.; Yang, J.H.; Whitehead, C. Affordability: Definitions, Measures and Implications for Lenders; University of Cambridge, Department of Land Economy: Cambridge, UK, 1994.

31. Freeman, A.; Chaplin, R.; Whitehead, C. Rental Affordability: A Review of International Literature. Discussion Paper No. 88; Department of Land Economy, Cambridge University: Cambridge, UK, 1997.

32. Field, C.G. Building consensus for affordable housing. Hous. Policy Debate 1997, 8, 801-832.

33. Brownill, S.; Sharp, C.; Jones, C.; Merrett, S. Housing London; Joseph Rowntree Foundation: England, UK, 1990.

34. Burke, T. Measuring Housing Affordability; Australian Housing and Urban Research Institute Swinburne-Monash Research Centre: Sydney, Australia, 2004.

35. Bogdon, A.S.; Can, A. Indicators of local housing affordability: Comparative and spatial approaches. Real Estate Econ. 1997, 25, 43-80.

36. Belsky, E.S.; Goodman, J.; Drew, R. Measuring the Nation's Rental Housing Affordability Problems; Harvard University, Joint Center for Housing Studies: Cambridge, UK, 2005.

37. Rowley, S.; Ong, R. Housing Affordability, Housing Stress and Household Wellbeing in Australia Final Report No. 192; Australian Housing and Urban Research Institute: Melbourne, Australia, 2012. 
38. Thalmann, P. “House poor” or simply “poor”? J. Hous. Econ. 2003, 12, 291-317.

39. Malpass, P. Housing Tenure and Affordability: The British Disease. In The New Housing Shortage: Housing Affordability in Europe and the USA; Hallett, G., Ed.; Routledge: London, UK, 1993; pp. 87-88.

40. Stone, M.E.; Burke, T.; Ralston, L. The Residual Income Approach to Housing Affordability: The Theory and the Practice Positioning Paper No. 139; Australian Housing and Urban Research Institute: Melbourne, Australia, 2011.

41. Leishman, C.; Rowley, S. Affordable housing. In The Sage Handbook of Housing; Clapham, D.F., Clarke, A.V., Gibb, K., Eds.; Sage: London, UK, 2012.

42. Australian Conservation Foundation and Victorian Council of Social Service (ACF \& VCOSS). Housing Affordability: More than Rents and Mortgages, 2008. Available online: http://www.vcoss.org.au/documents/VCOSS\%20docs/Housing/REP_ACF_VCOSS\%20Housing \%20Affordability\%20October\%202008\%20.PDF (accessed on 20 October 2014).

43. Seelig, T.; Phibbs, P. Beyond the Normative: Low Income Private Renters' Perspectives of Housing Affordability and Need for Housing Assistance. Urban. Policy Res. 2006, 24, 53-66.

44. Jones, C.; Watkins, C.; Watkins, D. Measuring local affordability: Variations between housing market areas. Int. J. Hous. Markets Anal. 2011, 4, 341-356.

45. Nepal, B.; Tanton, R.; Harding, A. Measuring housing stress: How much do definitions matter? Urban. Policy Res. 2010, 28, 211-224.

46. Haffner, M.; Heylen, K. User costs and housing expenses towards a more comprehensive approach to affordability. Hous. Stud. 2011, 26, 593-614.

47. McCord, M.; McGreal, S.; Berry, J.; Haran, M.; Davis, P. The implications of mortgage finance on housing market affordability. Int. J. Hous. Markets Anal. 2011, 4, 394-417.

48. Center for Transit-Oriented Development and Center for Neighborhood Technology (CTOD \& CNT). The Affordability Index: A New Tool for Measuring the True Affordability of a Housing Choice; Urban Markets Initiative, The Brookings Institution: Washington, DC, USA, 2006.

49. MacKillop, F. Sustainable as a basis of affordable? Understanding the affordability "crisis" in Australian housing. Aust. Plan. 2013, 50, 2-12.

50. Prochorskaite, A.; Maliene, V. Health, well-being and sustainable housing. Int. J. Strat. Prop. Manag. 2013, 17, 44-57.

51. Winston, N. Sustainable communities? A comparative perspective on urban housing in the European Union. Eur. Plan. Stud. 2014, 22, 1384-1406.

52. Wood, G.; Smith, S.J.; Ong, R.; Cigdem, M. The Edges of Home Ownership Final Report No. 216; Australian Housing and Urban Research Institute: Melbourne, Australia, 2013.

53. Mulliner, E.; Maliene, V. Criteria for Sustainable Housing Affordability. In Proceedings of the 8th International Conference on Environmental Engineering, Vilnius, Lithuania, 19-20 May 2011; pp. 966-973.

54. Office of the Deputy Prime Minister. The Egan Review: Skills for Sustainable Communities; RIBA Enterprise: London, UK, 2004.

55. Pallant, J. SPSS Survival Manual, 2nd ed.; Open University Press: Buckingham, UK, 2005.

56. Communities and Local Government. Strategic Housing Market. Assessments: Practice Guidance Version 2; The Stationary Office: London, UK, 2007. 
57. National Housing and Planning Advice Unit. Housing Affordability: A Fuller. Picture; National Housing and Planning Advice Unit: Fareham, UK, 2010.

58. Shelter. ROOF Affordability Index 2006; Shelter: London, UK, 2006.

59. Maliene, V.; Malys, N. High-quality housing-A key issue in delivering sustainable communities. Build. Environ. 2009, 44, 426-430.

60. Office of the Deputy Prime Minister. Sustainable Communities: Homes for All; The Stationary Office: London, UK, 2005.

61. Winston, N. Regeneration for Sustainable Communities? Barriers to Implementing Sustainable Housing in Urban Areas. Sustain. Dev. 2010, 18, 319-330.

62. Yates, J.; Milligan, V.; Berry, M.; Burke, T.; Gabriel, M.; Phibbs, P.; Pinnegar, S.; Randolph, B. Housing Affordability: A 21st Century Problem, National Research Venture 3: Housing affordability for lower income Australians Final Report No. 105; Australian Housing and Urban Research Institute: Melbourne, Australia, 2013.

63. Robinson, M.; Scobie, G.M.; Hallinan, B. Affordability of Housing: Concepts, Measurement and Evidence Working Paper No. 06/03; New Zealand Treasury: Wellington, New Zealand, 2006.

64. Office of the Deputy Prime Minister. Sustainable Communities: People, Places and Prosperity; The Stationery Office: London, UK, 2005.

65. Samuels, I. What Home Buyers Want: Attitudes and Decision Making Among Consumers; Commission for Architecture and the Built Environment: London, UK, 2005.

66. Zhu, X.; Liu, S.; Yeow, M.C.A. GIS-Based Multi-Criteria Analysis Approach to Accessibility Analysis for Housing Development in Singapore. In Proceedings of the SSC 2005 Spatial Intelligence, Innovation and Praxis: The National Biennial Conference of the Spatial Sciences Institute, Spatial Sciences Institute, Melbourne, Australia, 12 September 2005.

67. Communities and Local Government. Delivering Affordable Housing; Communities and Local Government: London, UK, 2006.

68. Pullen, S.; Arman, M.; Zillante, G.; Zuo, J.; Chileshe, N.; Wilson, L. Developing an assessment framework for affordable and sustainable housing. Australas. J. Constr. Econ. Build. 2010, 10, 48-64.

69. Prime Minister's Strategy Unit and Office of the Deputy Prime Ministe. Improving the Prospects of People Living in Areas of Multiple Deprivation in England; Cabinet Office: London, UK, 2005.

70. Clapham, D.; Mackie, P.; Orford, S.; Thomas, I.; Buckley, K. The housing pathways of young people in the UK. Environ. Plan. A 2014, 46, 2016-2031.

71. Pittini, A. Housing affordability in the EU: Current situation and recent trends. Cecodhas Hous. Eur. Obs. Res. Brief. 2012, 5, 6.

72. Thomsen, J. Reflections on the opportunities of urban planning to promote non-vehicular transportation in a sustainable settlement in Norway. Urban. Des. Int. 2011, 16, 162-170.

73. Communities and Local Government. National Planning Policy Framework; Communities and Local Government: London, UK, 2012.

74. McDonald, S.; Malys, N.; Maliene, V. Urban regeneration for sustainable communities: A case study. Technol. Econ. Dev. Econ. 2009, 15, 49-59.

75. Ryan, T.P. Nonparametric Methods, in Sample Size Determination and Power; John Wiley \& Sons Inc: Hoboken, NJ, USA, 2013. 
76. Campello, M.; Graham, J.R.; Harvey, C.R. The real effects of financial constraints: Evidence from a financial crisis. J. Financ. Econ. 2010, 97, 470-487.

(C) 2014 by the authors; licensee MDPI, Basel, Switzerland. This article is an open access article distributed under the terms and conditions of the Creative Commons Attribution license (http://creativecommons.org/licenses/by/4.0/). 